\title{
Maize fields are a potential sink for an outbreaking mirid bug pest in Chinese Bt-cotton agricultural landscapes
}

\author{
Zhenbiao Jiao ${ }^{1}$, Coline C. Jaworski ${ }^{2,3}$, Yanhui $\mathrm{Lu}^{1}$, Lefu $\mathrm{Ye}^{1}$, Kongming $\mathrm{Wu}^{1 *}$, Nicolas \\ Desneux ${ }^{4 *}$ \\ ${ }^{1}$ State Key Laboratory for Biology of Plant Diseases and Insect Pests, Institute of Plant Protection, Chinese Academy \\ of Agriculture Science, Beijing 100193, P.R. China. \\ ${ }^{2}$ Aix-Marseille Univ., Univ. Avignon, CNRS, IRD, Marseille, France. \\ ${ }^{3}$ Department of Zoology, University of Oxford, Oxford, OX1 3PS, U.K. \\ ${ }^{4}$ INRA (French National Institute for Agricultural Research), 400 route des chappes, 06903 Sophia Antipolis, France.
}

Z. Jiao and C. C. Jaworski contributed equally to the study.

*Corresponding authors

nicolas.desneux@inra.fr, kmwu@ippcaas.cn

Published in Agriculture, Ecosystems and Environment 279 (2019) 122-129, doi:

doi.org/10.1016/j.agee.2019.04.010

\begin{abstract}
Agricultural landscapes are fast-changing systems due to crop planting and harvesting. These events strongly influence movements of arthropod pests and their natural enemies, yet they are insufficiently considered to implement informed pest management strategies. In China, the adoption of Bt-cotton crops at very large scales has given rise to the recent pest status of mirid bugs such as Apolygus lucorum in cotton fields. In this study we relied on carbon 13 stable isotope analysis to estimate the dispersal of A. lucorum in the Bt-cotton agricultural landscape, composed of a mosaic of cotton and maize and other minor crops. We showed that a diet on $\mathrm{C}_{3}$-plants including cotton induced a significantly different signature than the $\mathrm{C}_{4}$-plant maize. Based on $\delta^{13} \mathrm{C}$ ratios, we showed that more than $75 \%$ of mirid bugs caught in maize fields did not originate in situ, since they had a $\mathrm{C}_{3}$-diet and therefore most likely dispersed from neighbouring cotton fields. Conversely, less than $10 \%$ of mirid bugs in cotton fields had a diet on $\mathrm{C}_{4}$-plants, so the vast majority of them did not disperse from maize fields but instead likely stayed in cotton fields. We also observed a delayed establishment of A. lucorum populations in maize fields compared to cotton fields, likely due to host phenology. Indeed we showed in laboratory that juveniles' survival rate and adults' fecundity are high on maize silk and grain only, whose resources are available in the field shortly before harvest. Unidirectional movements of mirids from cotton to maize associated with poor developmental success on maize highlight the high potential of maize fields to act as a sink for A. lucorum mirid bug pests. This could be wisely implemented in IPM programs to enhance the management of mirid bug population outbreaks in cotton fields and reduce yield loss on cotton.
\end{abstract}

Keywords:

Apolygus lucorum; dispersal; crop turn-over; integrated pest management; mosaic landscape; spillover. 


\section{Introduction}

Characteristics of agricultural landscapes, such as crop and non-crop diversity and their spatio-temporal organization are determinant in outbreaks and spillovers of arthropod pests and their natural enemies (Tscharntke et al., 2007, 2012). Conversely to Europe and North America, most agricultural landscapes in China are a mosaic of small fields of diverse crops (Liu et al., 2013), and this is likely to affect the dispersal of pests from crop to crop differently than in monocultural landscapes. Understanding the spatio-temporal dynamics of arthropod communities in these specific landscapes is therefore essential to implement informed pest management strategies.

Landscape complexity affects population dynamics of both pests and their natural enemies (Aviron et al., 2016; Meisner et al., 2016; Vasseur et al., 2013). For instance, pest densities tend to be lower when the proportion of semi-natural habitats in the landscape increases, especially because it increases natural enemies' spillover into crops (Inclán et al., 2015; Veres et al., 2013). Source-sink dispersal of pests and their natural enemies also occurs from crop to crop due to the spatial and temporal heterogeneity of cropping areas (i.e., crop planting, harvesting, and removal of residues), with important consequences for pest management strategies (Carrière et al., 2006; Schneider et al., 2015; Venugopal et al., 2015; Vialatte et al., 2006). In source crops, arthropod populations have positive growth rates, while in sink crops, they tend to have negative growth rates, but do not go extinct thanks to the arrival of excess individuals from neighbouring source patches (Holt, 1985; Dias, 1996; Hanski, 1999; Holyoak, Leibold \& Holt, 2005). The role of specific crops as a source or sink of pests is also dynamic on a longer term and may be altered by widescale adoptions of particular agricultural and landscape management practices (Zeilinger et al., 2016). This is the case of cotton crops in China, that have changed from sinks to sources of pests. Indeed, the wide-scale use of $\mathrm{Bt}$ cotton and the correlated decrease in insecticide use have lead to important outbreaks of mirid bugs in Bt cotton fields, eventually becoming new pests ( $\mathrm{Lu}$ et al., 2012a, 2010a; Lu \& Wu, 2011). In addition, mirid bugs develop well on cotton resources, especially when flower resources are available (i.e., from July to August; Dong et al. 2013). However, the contextual source or sink role of specific crops, as well as arthropod movements in multicrop landscapes is poorly understood.

Stable isotope analysis of phytophagous arthropod bodies is a valuable tool to assess inter-seasonal movements between host plants (di Lascio et al., 2016; Raymond et al., 2015; Vialatte et al., 2006). A diet composed of plants using either a $\mathrm{C}_{3^{-}}$or a $\mathrm{C}_{4}{ }^{-}$ photosynthetic pathway will result in a measurable different ratio of ${ }^{13} \mathrm{C}$ over ${ }^{12} \mathrm{C}\left(\delta^{13} \mathrm{C}\right)$ in the insect's body (Prasifka \& Heinz, 2004). This can be used to retrace the dispersal history of insects between successive host plants, such as different crops. For instance, cotton is a $\mathrm{C}_{3}$ plant, and maize is a $\mathrm{C}_{4}$ plant. Combining data on location of capture and $\delta^{13} \mathrm{C}$ ratio of pests in a landscape composed of both crops can help to unveil major diet resources and movements of individuals in the agricultural landscape, provided that the differences in $\delta^{13} \mathrm{C}$ ratios of the studied insects have been established beforehand on the target crops (Vialatte et al., 2006).

As a consequence of the wide-scale use of $\mathrm{Bt}$ cotton in China and the correlated decrease in insecticide use (Lu et al., 2012a; Lu \& Wu, 2011), mirid bugs have known important outbreaks in Bt cotton fields, eventually becoming new pests, as it is the case for Apolygus lucorum (Li et al., 2011; Lu et al., 2010a). Although it can prey on Lepidoptera eggs and other small prey, A. lucorum feeds mostly on plants (Li et al., 2015; Li et al., 2016) and can cause high levels of damage on cotton crops (Lu \& Wu, 2011). Chemical control methods have been developed against $A$. lucorum, which in turn became resistant to a number of chemicals (Zhang et al., 2015). Alternative strategies, such as RNA interference of semiochemical detection (Zhou et al., 2014), trap crops (Lu et al., 2009) and the use of biocontrol agents (Luo et al., 2014; Tong et al., 2009) are currently being developed. Despite the strong evidence that A. lucorum populations disperse across different host plant crops seasonally (Lu et al., 2010b; Song et al., 2012a, b, Pan et al. 2015), few pest management strategies have integrated those landscape-scale movements so far. In this context, investigating which crop is source versus sink for A. lucorum should provide valuable tools to improve pest management strategies against this new pest.

In the present study, we investigated the spillover of A. lucorum between cotton and maize crops in a Chinese agricultural landscape. We verified and validated the use of $\delta^{13} \mathrm{C}$ ratios as an indicator of the diet of A. lucorum on a variety of host plants, and thus of the movement of mirid bug adults between crop fields. To do this, we first measured the sensitivity of the $\delta^{13} \mathrm{C}$ ratio in the body of $A$. lucorum to their diet on a diversity of $\mathrm{C}_{3}$ plants including cotton, and the $\mathrm{C}_{4}$ plant maize. Second, we measured how a directed host plant transfer between cotton and maize resources from juvenile to adult stage affected the isotopic signature of adults in laboratory conditions. We then monitored A. lucorum's population dynamics in both cotton and maize fields during three summers, and we also caught some adults to measure their $\delta^{13} \mathrm{C}$ ratios. We estimated whether the $\delta^{13} \mathrm{C}$ ratios of those adults corresponded to a diet based on the crop from the field they were caught in, and deduced possible dispersal events between $\mathrm{C}_{3}$ crops (mostly cotton) and maize, the only $\mathrm{C}_{4}$ crop in the environment. Finally, we measured the life parameters of A. lucorum on maize tissue in laboratory conditions, to get insight on population growth in maize fields.

\section{Materials and Methods}

\subsection{Method validation: sensitivity of $\delta^{13} \mathrm{C}$ ratio to diet and directed host plant transfer}

To unambiguously relate specific $\delta^{13} \mathrm{C}$ ratios from mirid bugs caught in fields to their diet, and thus to their movements in the landscape, we first checked how a diet on a $C_{3}$ vs. a $C_{4}$ plant type, as well as a transfer between plant types affected $\delta^{13} \mathrm{C}$ ratios of mirid bugs in laboratory conditions. 
2.1.1. Biological material. A laboratory colony of A. lucorum was used, maintained at the Langfang Experimental Station of the Chinese Academy of Agricultural Sciences (CAAS), Hebei Province $\left(39.53^{\circ} \mathrm{N}\right.$, $116.70^{\circ} \mathrm{E}$ ) since 2005 , from individuals of A. lucorum collected in a cotton field near the station. Each year, new wild individuals were introduced into the colony to maintain its vigor and avoid genetic depression. The colony, composed of about 60 adults and 100 juveniles, was maintained in a $20 \times 10 \times 6 \mathrm{~cm}$ rearing container at $29 \pm 1{ }^{\circ} \mathrm{C}, 60 \pm 5 \% \mathrm{RH}$ and a 14:10 L:D photoperiod, with green beans leaves (Phaseolus vulgaris) and a cotton ball soaked with a 10\% sucrose solution (Lu \& Wu, 2008).

Nine species of $\mathrm{C}_{3}$ plants (cotton Gossypium hirsutum L., garden balsam Impatiens balsamina L., Japanese hop herb Humulus scandens (Lour.) Merr., green bean Phaseolus vulgaris L., castor-oil-plant Ricinus communis L., peanut Arachis hypogaea L., alfalfa Medicago sativa L., carrot Daucus carota L., sunflower Helianthus annuus L.) and one $\mathrm{C}_{4}$ plant (Maize Zea mays L.) were selected because these species are common host plants of A. lucorum in the agroecosystem of Northern China, as well as important crops in the region ( $\mathrm{Lu} \mathrm{\&} \mathrm{Wu}$, 2008). Maize is the only $\mathrm{C}_{4}$ plant found in abundance in the agricultural landscape. Cotton seeds were provided by the Biotechnology Research Institute, CAAS (Beijing), and the seeds of other plants (except the Japanese hop weed) were purchased from the local market. Alfalfa was planted in the spring of 2006, and managed according to local practices, including periodical cutting. Seedlings of Japanese hop herb were transplanted from local agroecosystem into experimental fields in late April. All the other plants were seeded in late April and also managed according to local agricultural practices. During the whole experimental period, no pesticide was used on all the tested plants.

\subsubsection{Sensitivity of $\delta^{13} \mathrm{C}$ ratio to type of diet during} the juvenile stage. In order to assess the impact of food diet during the juvenile stage on isotopic ratios of A. lucorum adults, we reared juveniles of A. lucorum on the selected nine $C_{3}$ plants and the $C_{4}$ plant. For each of those ten plants, tender leaves and buds were collected from the cultivated fields, and provided as an exclusive ad libitum food source, renewed daily, to A. lucorum juveniles. Juveniles were maintained individually in Petri boxes (diameter $10 \mathrm{~cm}$, height $1.5 \mathrm{~cm}$ ) in laboratory conditions from hatching to adulthood. Adults were placed individually in $1.5 \mathrm{ml}$ centrifuge tubes containing $95 \%$ ethanol just after emergence and stored at $-20^{\circ} \mathrm{C}$ prior to carbon isotope analysis. Sample sizes are provided in Fig. 1.

2.1.3. Sensitivity of $\delta^{13} \mathrm{C}$ ratio to a host plant transfer from juvenile to adult stages. Apolygus lucorum adults are active fliers and they usually move across fields and from crop to crop (Lu \& Wu, 2008; Pan et al., 2013). To evaluate the influence of a directed host plant transfer of $A$. lucorum individuals between $\mathrm{C}_{3}$ plants and $\mathrm{C}_{4}$ plants on their isotopic signature, A. lucorum adults reared on a maize versus cotton diet during the juvenile stage were transferred to a cotton versus maize diet following adult emergence, respectively, and maintained in Petri boxes in similar conditions as above. At the $0,3^{\text {rd }}, 6^{\text {th }}$, and $9^{\text {th }}$ day after host plant transfer, four to 27 individuals for each type of transfer (i.e., maize to cotton versus cotton to maize) were removed from the boxes and stored individually at $-20^{\circ} \mathrm{C}$ as described above for further isotope analysis. Sample sizes are provided in Fig. 2.

2.1.4. Stable isotope protocol. $\delta^{13} \mathrm{C}$ ratio analyses were conducted at the Stable Isotope Mass Spectrometry Facility at the Department of Chinese Academy of Forestry, China. On each adult stored for isotope analysis, the two forewings were removed using dissection scissors. Forewings develop during the juvenile stage, and conversely to other body parts, the $\delta^{13} \mathrm{C}$ signature obtained from this tissue changes less rapidly than other body parts in adults experiencing a different type of diet than during their juvenile stage. Therefore, forewings allow a remote tracking of mirids movements in the environment. The wings were weighed (Mettler Toledo Million molecular micro balance) and approximately $0.05-0.09 \mathrm{mg}$ of wing material was placed into $5 \times 9 \mathrm{~mm}$ tin capsules. Samples were analyzed using an Element Analyzer (Flash EA1112HT Thermo Fisher Scientific, Inc. USA) coupled to a DELTA V Advantage Isotope Ratio Mass Spectrometer, with a Conflo III Interface to measure $\delta^{13} \mathrm{C}$ ratios (Gould et al., 2002). International standards GLY and URFA were used as isotope references. Isotope ratios were calculated as follows: $\delta^{13} \mathrm{C}=\left[\left(R_{\text {sample }} / R_{\text {standard }}\right)-1\right] \times 10^{3}$, where $R=$ ${ }^{13} \mathrm{C} /{ }^{12} \mathrm{C}$. Calculated $\delta^{13} \mathrm{C}$ values were accurate to less than $0.1 \%$.

2.1.5. Statistical analysis of $\delta^{13} \mathrm{C}$ ratios' sensitivity to diet. The $\delta^{13} \mathrm{C}$ values of $A$. lucorum adults fed on the ten different plant species during their juvenile stage were analyzed using a one-way ANOVA with the plant species as factor. Residuals were normally distributed (Shapiro test: $\mathrm{W}=0.98353, P=0.54$ ) and the assumption of homoscedasticity was respected (Breusch-Pagan test: $\mathrm{BP}=10.74$, $\mathrm{df}=9, P=0.29$; function 'bptest' in the $\mathrm{R}$ library 'Imtest'). The ANOVA test was followed by a Tukey's HSD test (Supplementary Materials Table S1). All analyses were performed with $\mathrm{R}$ version 3.2.3 (R Core Team, 2015).

The effect of a host plant transfer between juvenile and adult stage on $\delta^{13} \mathrm{C}$ ratios of $A$. lucorum adults was analyzed using two one-way ANOVA tests for the two independent transfer datasets. Residuals were normally distributed (Shapiro test: Maize to cotton: $W=0.99204$, $P=0.99$; Cotton to maize: $\mathrm{W}=0.96598, P=0.13$ ) and the assumption of homoscedasticity was respected (Breusch-Pagan test: Maize to cotton: $\mathrm{BP}=2.16$, $\mathrm{df}=1$, $P=0.14$; Cotton to maize: $\mathrm{BP}=0.044$, $\mathrm{df}=1, P=0.83$ ). The differences in mean $\delta^{13} \mathrm{C}$ ratios between days within one type of transfer were estimated by a Tukey's HSD test (Table S2), and the differences between types of transfer for a same day were estimated by a Welch two-sample $t$ test, which allows unequal variances between compared groups.

\subsection{Dispersal of A. lucorum between maize and cotton fields}

2.2.1. Population monitoring at the Langfang Experimental Station. We used the carbon 13 stable 
isotope analysis calibrated above to measure the dispersal of A. lucorum adults between cotton and maize fields from July to September 2009, 2010 and 2013 at the Langfang Experimental Station. Each year, three plots seeded with cotton and three plots seeded with maize of about $400 \mathrm{~m}^{2}$ were seeded in late April, at a density of 30,000 and 60,000 plants per hectare, respectively. Plots sown with cotton versus maize were randomly arranged, with a $3 \mathrm{~m}$ distance between two adjacent plots. Classical cultural practices were applied, except that no pesticide was used. Every fourth or fifth day from July to September 2009, 2010 and 2013, five groups of 20 to 30 plants at five random locations per plot were visually inspected, and the number of adults and juveniles of A. lucorum was recorded and reported as a density, i.e. number of individuals per 100 plants. In the same field plots but on other groups of plants, as many adults of A. lucorum as possible (less than five per plot per collection day) were caught with sweep nets. When reaching maize tassels and silks with the net, adults took off and were easily caught. They were stored individually at $-20{ }^{\circ} \mathrm{C}$ as described above for further $\delta^{13} \mathrm{C}$ analysis. No adults were caught in maize fields on July 2009 and 2013 due to very low densities. The number of adults analyzed per month and crop is provided in Fig. $3 . \delta^{13} \mathrm{C}$ ratios were measured following the protocol described above.

2.2.2. Statistical analysis of $\delta^{13} \mathrm{C}$ ratios from mirid adults caught in maize and cotton fields. Following the results from our sensitivity analysis of $\delta^{13} \mathrm{C}$ ratios to individuals' diet during their juvenile stage, $\delta^{13} \mathrm{C}$ ratios were classified into three types: diet mostly on $\mathrm{C}_{3}$ plants for values lower than $-18 \%$, diet mostly on $\mathrm{C}_{4}$ plants for values higher than $-15 \%$, and mixed diet otherwise. A diet mostly on $\mathrm{C}_{4}$ plants was assumed to correspond to a diet on maize, since this is the only abundant $\mathrm{C}_{4}$ plant in the environment. Similarly, cotton is the most abundant $\mathrm{C}_{3}$ plant in the environment, and was assumed to make the bulk of the diet of $\mathrm{C}_{3}$-marked individuals. Therefore, if the main diet at the juvenile stage did not correspond to the crop in which the adults were caught, adults were assumed to have dispersed from one field crop to the other at the adult stage. Intermediate values likely corresponded to a complex dispersal history of individuals, and were thus not used in the analysis. Each year, individuals caught in a given month were pooled. Proportions of adults whose diet corresponds to the field crop were calculated as the number of adults with a diet mostly on $\mathrm{C}_{4}$ versus $\mathrm{C}_{3}$ plants, divided by the total number of adults caught in each field per month, in maize versus cotton fields respectively. The effect of field crop on those proportions was analyzed using a weighted one-way ANOVA test, with the field crop as a factor and the total number of adults caught in each field per month as weight to account for non-homogeneous variance due to different sampling sizes. Residuals were normally distributed (Shapiro test: $\mathrm{W}=0.89667, \quad P=0.071$ ) and the assumption of homoscedasticity was respected (BreuschPagan test: $\mathrm{BP}=0.0002732$, $\mathrm{df}=1, P=0.99$ ).

2.2.3. Statistical analysis of population densities. To test whether densities of A. lucorum were higher in cotton than in maize fields, we performed a Kruskall-Wallis test on log-transformed pooled densities of adults and juvenile individuals. This test is used for non-normal data without violation of homoscedasticity among groups (cotton versus maize densities, Breusch-Pagan test: $\mathrm{BP}=4.16$; $\mathrm{df}=1 ; P=0.72$ ). To test whether A. lucorum colonizes maize fields later than cotton fields, we focused on the first day for which non-null densities were detected in each field and year, expressed in number of days since July $1^{\text {st }}$ of the year. We investigated how this first day varied according to the type of crop (maize versus cotton), the stage of individuals (adult versus juvenile) and the year (2009, 2010 or 2013, implemented as a factorial variable) as well as second-order interactions between those effects using a Cox proportional hazards regression model on a left-truncated right-censored survival function (R library survival). The arguments of the survival function were the first sampling date minus one as starting time, the first day with positive densities as ending time, and a one-level factorial variable as status, since we always detected positive densities at least once during the field season. The most likely model was obtained by the removal of non-significant interactions between effects, and the significance of interactions was assessed by a type-II comparison of models based on an analysis of variance.

\subsection{Life parameters of A. lucorum on maize plant tissues}

To link the population growth of A. lucorum in maize fields with the phenology of maize plants, we conducted a complementary analysis in laboratory conditions on the performance of A. lucorum on four different maize tissues: grain, silk, bract and tassel. Apolygus lucorum adults came from the lab colony (see section 2.1.1). Maize plants were produced in a greenhouse at the Langfang station in early May 2013, and they were managed according to local agronomic practices and without pesticide application. Fresh maize plant tissues (grain, silk, bract and tassel) were collected on those plants and used in the experiment (conducted in growth chambers, $25 \pm 1{ }^{\circ} \mathrm{C}, 60 \pm 5 \% \mathrm{RH}$ and 14:10 L:D).

Juvenile development and survival were measured on newly hatched juveniles collected from the laboratory colony and raised individually in glass vials $(3 \mathrm{~cm}$ high, $3 \mathrm{~cm}$ diameter) covered with nylon. They were given ad libitum maize plant tissue of one type only (grain, silk, bract or tassel). Plant material was replaced every day with fresh one. Eight, three, four and three cohorts of 30 individuals were used on grain, silk, tassel and bract maize tissues, respectively. Each day, the emergence of adults (corresponding to the full duration of juvenile development) or death of juveniles was assessed. Longevity and fecundity of adults were assessed on mating pairs of newly emerged adults, placed in glass vials with one of the four maize plant tissues. Plant material was changed daily and inspected for the presence of eggs. 40, 25, 20 and 20 mating pairs were used on grain, silk, tassel and bract maize tissues, respectively.

Statistical analysis. The survival rate of juveniles was analyzed using a one-way ANOVA with the type of maize tissue as factor. The residuals of the best model were normally distributed (Shapiro test: $\mathrm{W}=0.96534$, $P=0.71$ ) and homoscedasticity among groups was 
respected (Breusch-Pagan test: $\mathrm{BP}=3.5673, \mathrm{df}=3$, $P=0.31$ ). Because of deviation to normality, the effect of maize tissue on the duration of juveniles' development and on adults' longevity was assessed using Generalized Linear Models (GLMs) with an inverse gaussian distribution and a Gamma distribution, respectively, selected against competing distributions using the AIC/BIC criteria. The fixed effects were the type of maize tissue, as well as the sex and the second order interaction between simple effects for adults' longevity. Significance of effects was estimated through a type-II comparison of models, based on Fischer's tests. The most likely model was obtained by sequential removal of the interaction and the non significant simple effect. The effect of maize tissue on fecundity was assessed using a GLM with a Poisson distribution, due to the presence of null values. For each data set, a Tukey's HSD test was performed on the best model to compare means between treatments (Tables S3-6).

\section{Results}

3.1. Effect of diet at the juvenile stage on $\delta^{13} \mathrm{C}$ ratios of A. lucorum

The plant species used to feed juveniles had a significant effect on the $\delta^{13} \mathrm{C}$ ratios of $A$. lucorum adults (One-way ANOVA: $F_{9,55}=436.37 ; P<0.001$; Fig. 1 ). $\delta^{13} \mathrm{C}$ ratios were always higher than -15 on maize (the only $\mathrm{C}_{4}$ plant), and lower than -22 for adults reared on $\mathrm{C}_{3}$ plants. Differences in $\delta^{13} \mathrm{C}$ ratios among $\mathrm{C}_{3}$ plants were marginal (Tukey HSD-test, Fig. 1 and Table S1).

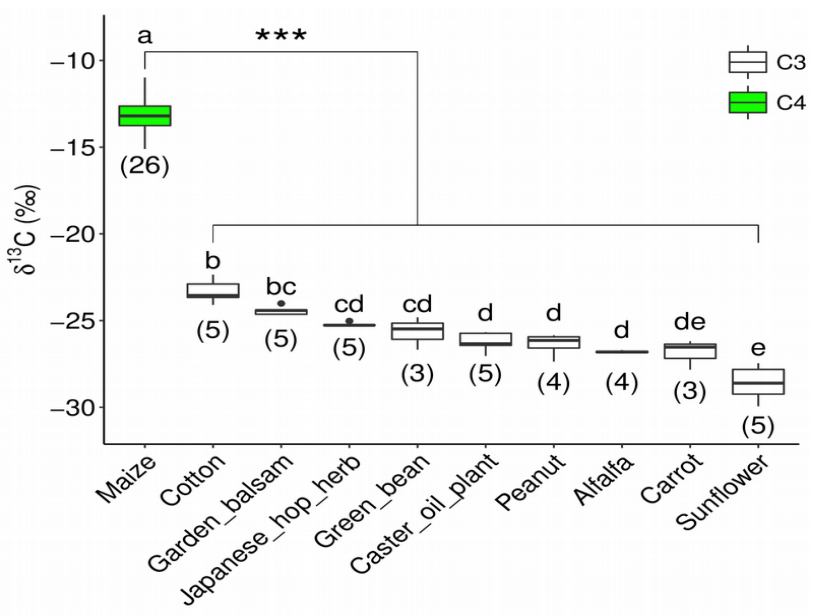

Fig. 1. $\delta^{13} \mathrm{C}$ ratios of $A$. lucorum adults fed on different plant species during the juvenile stage. Boxplots showing median, $1^{\text {st }}$ and $4^{\text {th }}$ quantile, minimum and maximum values. Numbers in parentheses are the number of replicates for each treatment. Letters correspond to pairwise comparisons from Tukey's HSD test. $\delta^{13} \mathrm{C}$ ratios of $A$. lucorum adults fed on maize (the only $\mathrm{C} 4$ plant) were significantly different from those on all the C3 plants (marked as '***', ANOVA test).

The host plant transfer from maize to cotton of A. lucorum between juvenile and adult stages caused a marginal decrease in $\delta^{13} \mathrm{C}$ ratios of $A$. lucorum adults, but day-to-day means were not significantly different (Oneway ANOVA: $F_{1,43}=5.21, P=0.028$; Fig. 2 and Table S2). $\quad \delta^{13} \mathrm{C}$ ratios of $A$. lucorum were still higher than -15 nine days after the transfer. Conversely, the transfer from cotton to maize caused a strong increase in $\delta^{13} \mathrm{C}$ ratios of A. lucorum adults (One-way ANOVA: $F_{1,51}=56.88$, $P<0.001$ ), which remained different from those corresponding to a maize to cotton transfer through day 0 to 9 ( $t$-tests; day 9: $t=-7.91$, $\mathrm{df}=9.13, P<0.001$; day 6 : $t=-16.0, \quad \mathrm{df}=33.1, \quad P<0.001 ; \quad$ day $3: \quad t=-15.02$, $\mathrm{df}=8.74, \quad P<0.001 ; \quad$ day $\quad 0: \quad t=-27.9, \quad \mathrm{df}=7.58$, $P<0.001)$.

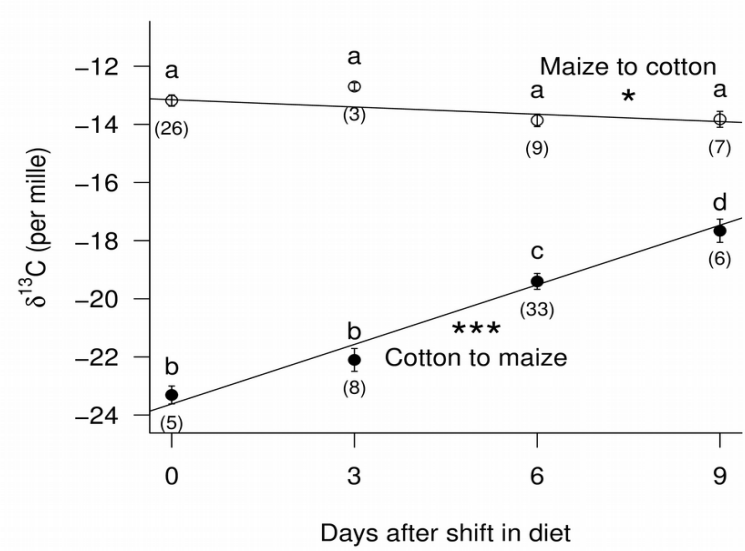

Fig. 2. Change in $\delta^{13} \mathrm{C}$ ratios of $A$. lucorum adults after a host plant transfer from juvenile to adult stage, between cotton $\left(\mathrm{C}_{3}\right)$ and maize $\left(\mathrm{C}_{4}\right)$ plants. Individuals from the group "Maize to cotton" were fed with maize at the juvenile stage and cotton at the adult stage, and the opposite is true for individuals from the group "Cotton to maize”. A transfer from maize to cotton induced a marginally significant decrease in $\delta^{13} \mathrm{C}$ ratios with no significant differences between day-to-day means, while a transfer from cotton to maize induced a strongly significant increase in $\delta^{13} \mathrm{C}$ values (***, ANOVA test). Dots represent means \pm SE. Letters represent significant differences between treatments (Tukey's HSD test, $P<<0.01)$.

Based on the above results and similarly to previous studies (Baker \& Tann, 2013; Gould et al., 2002; Head et al., 2010; Vialatte et al., 2006), and to be able to estimate adults dispersal between crops from field data, we confirmed that $A$. lucorum adults with $\delta^{13} \mathrm{C}$ ratios lower than $-20 \%$ versus higher than $-15 \%$ o unambiguously experienced a diet mostly based on $\mathrm{C}_{3}$ versus $\mathrm{C}_{4}$ plants during the juvenile stage, respectively (Fig. 2). Individuals with intermediate values ranging from $-20 \%$ to $-18 \%$ also unambiguously experienced a $\mathrm{C}_{3}$ plantbased diet during the juvenile stage, with a possible recent shift to a $\mathrm{C}_{4}$ plant-based diet at the adult stage (Fig. 2). Other individuals with $\delta^{13} \mathrm{C}$ ratios between $-18 \%$ and $15 \%$ cannot be unambiguously assigned to either type of diet during the juvenile stage. In field conditions, juveniles' diet is restricted to the host plant they emerge on since they are not mobile, hence their $\delta^{13} \mathrm{C}$ signature should be unambiguous. Conversely, non-newly emerged adults may have experienced different types of diet thanks to their ability to disperse and forage on different resources, and this would result in a mixed $\delta^{13} \mathrm{C}$ signature with no possibility to unambiguously assign such individuals to a unique type of diet or a chrono-sequence of diets. Therefore in the following analysis of field measurements, we used adults with $\delta^{13} \mathrm{C}$ ratios lower than $-18 \%$ and higher than $-15 \%$ only, assumed to have experienced a diet mostly on cotton and maize, respectively, at the juvenile stage. 
3.2. Dispersal of A. lucorum between maize and cotton fields: estimating dispersal events from $\delta^{13} \mathrm{C}$ ratios

Figure 3 shows the proportion of adults caught in maize and cotton fields whose measured $\delta^{13} \mathrm{C}$ ratios correspond to a diet on their field crop. These proportions are significantly smaller in maize than in cotton (Oneway, weighted ANOVA: $\left.F_{1,14}=91.61 ; P<0.001\right)$, with a mean of $23.5 \%$ and $90.4 \%$ of adults with $\delta^{13} \mathrm{C}$ ratios corresponding to a diet mostly on maize in maize fields and cotton in cotton fields, respectively. This means that most adults caught in maize fields did not originate in maize fields, but instead likely dispersed from neighbouring cotton fields. Conversely, most adults caught in cotton fields likely did not disperse.

Figure 4 shows the population dynamics of adults and juveniles of A. lucorum in maize and cotton fields. Densities were highly variable across years and especially low in 2013, but always peaked in August, coinciding with the end of the flowering stage of cotton, and the flowering / fruiting stage of maize. Densities were significantly higher in cotton fields than in maize fields (Kruskall-Wallis $\mathrm{Chi}^{2}=28.69$; $\mathrm{df}=1 ; P<0.001$ ), with a seasonal mean of 18.53 and 7.76 individuals per 100 plant (adults and juveniles pooled) in cotton versus maize fields, respectively.

We tested whether the first day at which positive densities were measured in maize and cotton fields depended on the type of crop, the type of individuals and the year (Table 1 ). Juveniles of A. lucorum were observed slightly before adults in cotton fields; adults arrived later in maize fields than in cotton fields and juveniles arrived even after adults in maize fields (Table 1, Fig. S1). The first day with positive densities was earlier in 2010 than 2009 but later in 2013 than 2009.

Table 1. Analysis of the first day at which positive densities of A. lucorum individuals were measured at the Langfang station in cotton and maize fields in 2009, 2010 and 2013. ANOVA tests were carried out on Cox models modeling the probability to observe positive densities after a certain time, with type of crop, individual stage (adult or juvenile) and year, as well as the second order interactions between those effects implemented as fixed effects. Each fixed effect was tested by controlling for the influence of all other fixed effects of equal or lower degree. The parameter estimates (under their exponential form, as implemented in Cox survival models) as well as their $95 \%$ confidence intervals have been estimated on the most likely model obtained by removal of the non-significant second-order interaction.

\begin{tabular}{|c|c|c|c|}
\hline Fixed effect & t. f. & $x^{2}$ & $P$-value \\
\hline Crop $\times$ Year & 2 & 11.36 & $0.0034 * *$ \\
\hline Crop $\times$ Stage & 1 & 12.30 & $0.00045 * * *$ \\
\hline Year $\times$ Stage & 2 & 3.99 & 0.14 \\
\hline Fixed effect & & 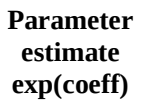 & $\begin{array}{c}95 \% \text { confidence } \\
\text { interval }\end{array}$ \\
\hline Crop $=$ maize & & 1.45 & {$[0.31 ; 7.03]$} \\
\hline Stage $=$ juvenile & & 1.08 & {$[0.36 ; 3.19]$} \\
\hline Year $=2010$ & & $2.07 e+8$ & {$[4.69 \mathrm{e}+7 ; 9.16 \mathrm{e}+8]$} \\
\hline Year $=2013$ & & 0.58 & {$[0.13 ; 2.63]$} \\
\hline Crop $=$ maize $\&$ Stage $=$ juveni & nile & 0.032 & {$[0.0038 ; 0.27]$} \\
\hline Crop $=$ maize $\&$ Year $=2010$ & & $7.66 \mathrm{e}-10$ & [7.66e-10;7.66e-10] \\
\hline Crop $=$ maize $\&$ Year $=2013$ & & 0.058 & {$[0.0048 ; 0.70]$} \\
\hline
\end{tabular}

*** $P<0.001 ; * * P<0.01$.

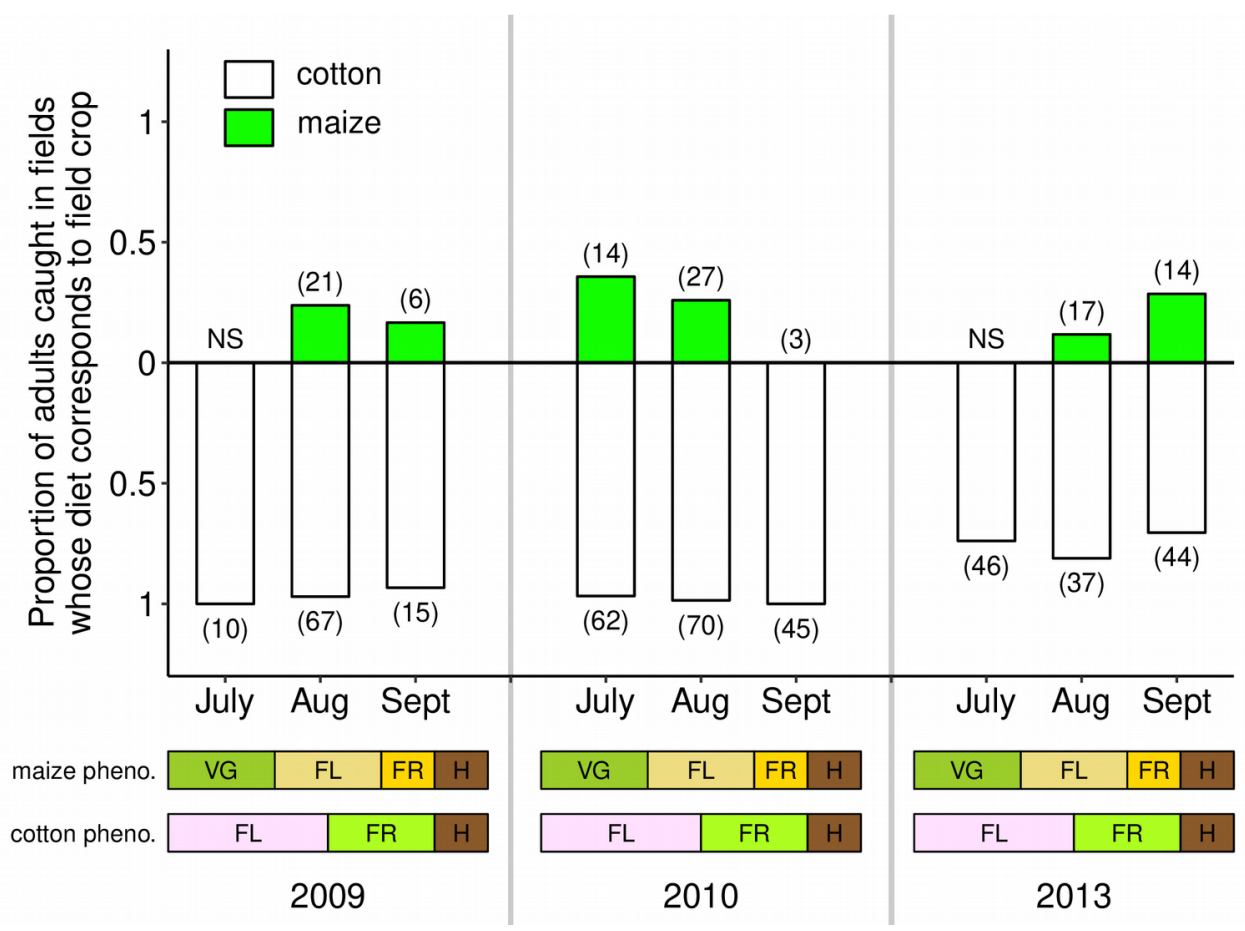

Fig. 3. Proportion of A. lucorum adults caught in maize versus cotton fields, and whose diet at the juvenile stage corresponds to field crop (C $\mathrm{C}_{4}$ versus $\mathrm{C}_{3}$ plants), in summers 2009, 2010 and 2013 at the Langfang station. In maize fields, local (green) vs. dispersing individuals were assumed to have had a diet exclusively on maize $\left(\mathrm{C}_{4}\right.$-plant) vs. cotton at the juvenile stage, and had a $\delta^{13} \mathrm{C}$ value $>-15 \%$ vs. $<-18 \%$, respectively. In cotton fields, local (white) vs. dispersing individuals were assumed to have had a diet exclusively on cotton vs. maize at the juvenile stage, and had a $\delta^{13} \mathrm{C}$ value $<-$ $18 \%$ vs. $>-15 \%$, respectively. Individuals with intermediate values ( $>-18 \%$ and $<-15 \%$ ) likely had a mixed diet with more complex dispersal events and were not considered here. Numbers in brackets above and below bars are the sampling sizes for each date and crop field. "NS" means no sampling conducted at these dates. The phenology of maize and cotton crops is indicated by coloured bars below the x-axis ("VG": vegetative growth; "FL": flowering stage; "FR": fruiting stage; "H": harvest). Proportions of adults whose diet correspond to the crop field are significantly lower in maize than in cotton fields, implying that adults in maize fields dispersed from $\mathrm{C}_{3}$ plants, likely from neighbouring cotton fields. 


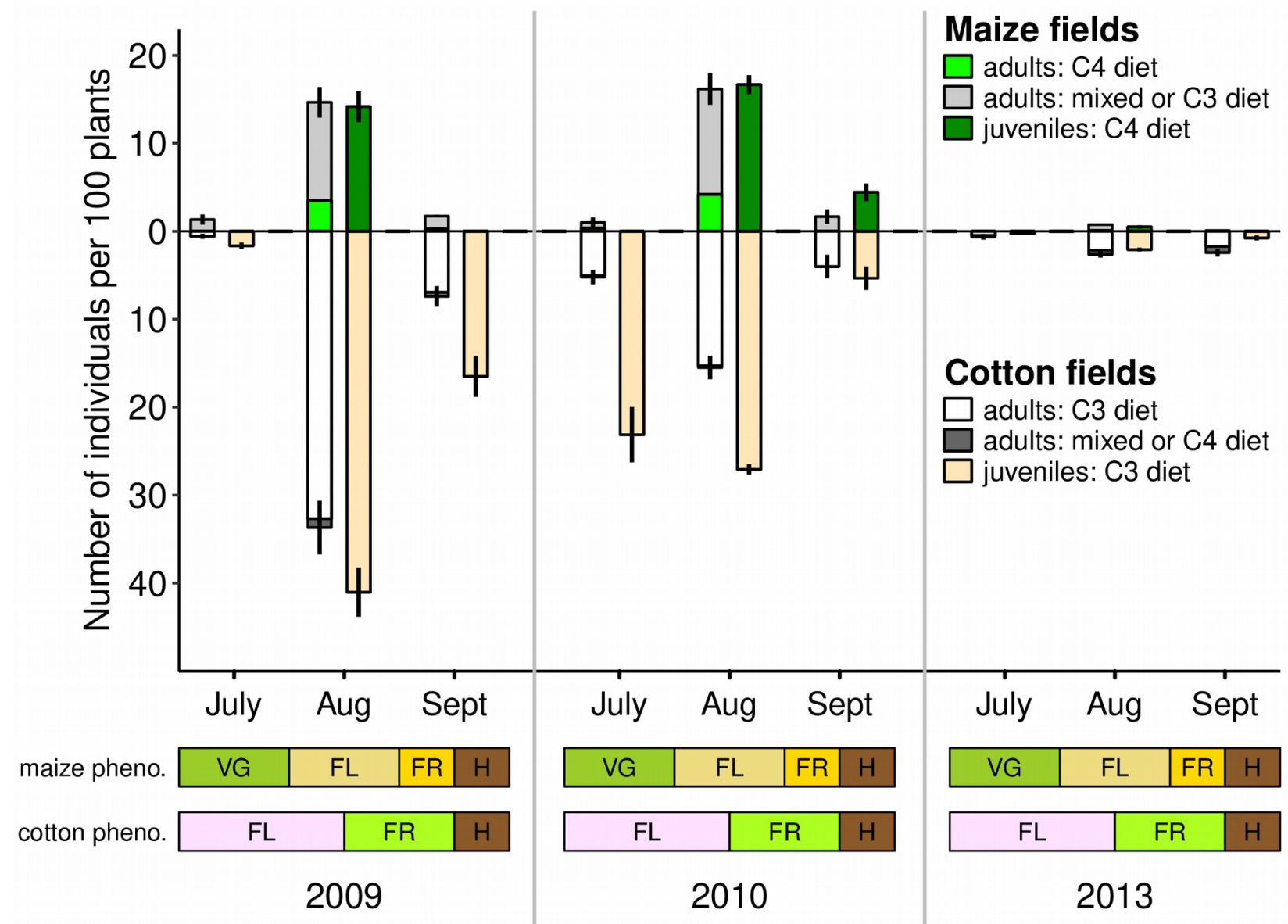

Fig. 4. Population dynamics of A. lucorum adults and juveniles in maize (top row) and cotton (bottom row) fields in summers 2009 , 2010 and 2013, at the Langfang station. Vertical lines at the end of bars are SE on the monthly mean of the three plots per field and month. Numbers of individuals with different diets have been estimated from proportions in Fig. 3. The phenology of maize and cotton crops is indicated by coloured bars below the X-axis ("VG": vegetative growth; "FL": flowering stage; "FR": fruiting stage; "H": harvest). Juveniles have been assumed to always have a diet on the crop from the field they were caught in, since they are not mobile.

\subsection{Life parameters of A. lucorum on four different maize tissues}

Figure 5 shows the life parameters of A. lucorum on four different types of maize tissues. The type of maize tissue had a significant effect on juvenile survival $\left(\mathrm{F}_{3,14}=29.56, \quad P<0.001\right)$, with considerably reduced survival on tassel and bract as compared to grain and silk (Fig. 5A, Table S3). The duration of juvenile development was also affected by the type of maize tissue $\left(\mathrm{F}_{3,136}=36.48, \quad P<0.001\right)$, and was shorter on grain, intermediate on silk and tassel, and longer on bract (Fig. 5B, Table S4). The type of maize tissue significantly affected the longevity of A. lucorum adults, but not the sex or the interaction between sex and type of plant tissue (plant tissue $*$ sex: $F_{3,203}=0.2084, P=0.89$; sex: $\quad F_{1,204}=3.5218, \quad P=0.062 ; \quad$ maize tissue: $\left.\mathrm{F}_{3,207}=105.31, P<0.001\right)$. Adults' longevity on maize grain and silk was 4-5 times longer than on tassel and bract (Fig. 5C, Table S5). The type of maize tissue significantly affected the fecundity of mating pairs of A. lucorum adults $\quad\left(\operatorname{Dev}_{3,101}=4679.5, \quad P<0.001\right)$. Fecundity was 5-68 times higher on maize grain than on the other maize tissues (Fig. 5D, Table S6).
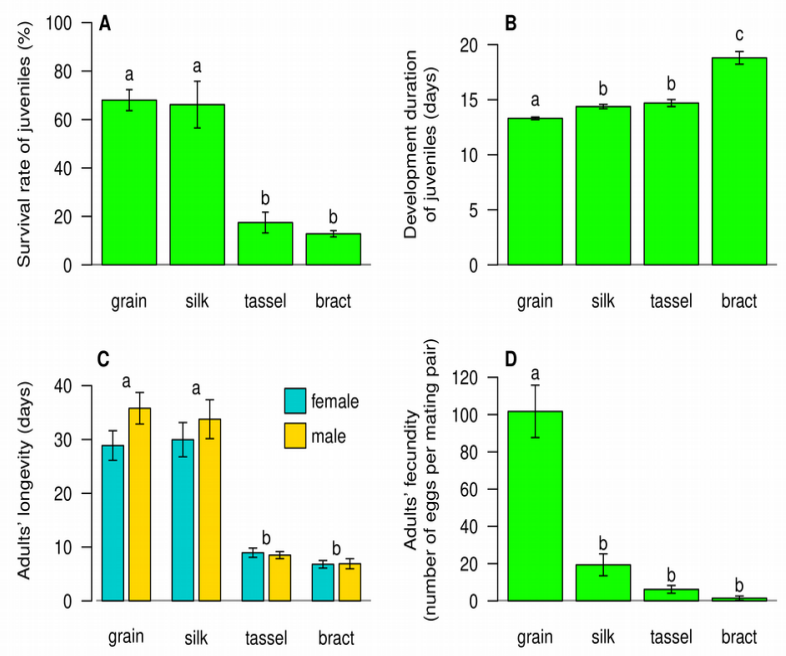

Fig. 5. Influence of the type of maize tissue on (A) the survival rate of A. lucorum juveniles; (B) the duration of their development; (C) the longevity of A. lucorum adults; and (D) their fecundity. Means \pm SE are presented. Different letters above the bars indicate significant differences between tissues (Tukey's HSD tests, Tables S3-6). For adult longevity, Tukey's HSD tests were conducted on pooled female (blue) and male (orange) individuals, since the sex had no effect on longevity. 


\section{Discussion}

The Chinese agricultural landscape is composed of a mosaic of small fields of different crops, and considering the consequences of this particular landscape structure on the dispersal of arthropod pests and their natural enemies may provide useful insights to implement informed pest management practices. In the present study, we measured the dispersal of the new cotton pest A. lucorum between the economically important crops cotton and maize, using stable isotopic ratios analyses. We first showed that it is possible to unambiguously differentiate A. lucorum adults having experienced a diet based on $\mathrm{C}_{3}$ plants (e.g. cotton) versus $\mathrm{C}_{4}$ plants (e.g. maize) at the juvenile stage, and their $\delta^{13} \mathrm{C}$ ratios remained different for nine days after a transfer to the alternative plant resource at the adult stage (Figs. 1,2). This allowed us to detect dispersal events between maize and cotton fields: most A. lucorum adults (>90\%) caught in cotton fields had developed on $\mathrm{C}_{3}$ plants (hence, presumably in situ). Conversely, only $23.5 \%$ of adults caught in maize fields had developed on $\mathrm{C}_{4}$ plants, and therefore likely dispersed from cotton to maize fields at the adult stage (Fig. 3). Finally, we showed that maize tissues do not allow a high performance of A. lucorum until silk and grain are formed (Fig. 5), which likely explains the delayed establishment of A. lucorum populations in maize fields (Fig. 4). Combined with dispersal data, those poor performances on maize reinforce the potential of maize fields to act as a sink for mirid bug pests from neighbouring source cotton fields in the North-eastern Chinese Bt-cotton agricultural landscape.

Dispersal of pest populations from source crop fields to sink crop fields has been reported in other agricultural landscapes, for pest species characterized by a reduced mobility at the juvenile stage and a winged adult stage, and especially hemipteran bugs. For instance, maize has been identified as being a source of English grain aphids (Sitobion avenae) for wheat fields in early autumn in Western France (Vialatte et al., 2006). Venugopal et al. (2015) showed that the pentatomid stink bug Halyomorpha halys dispersed from maize to soybean fields when soybean seeds began to develop. Carrière et al. (2006) found that forage and seed alfalfa were source crops for the pest mirid bug Lygus hesperus, while cotton was a sink in Central Arizona, and a similar pattern was reported in Meisner et al. (2016). This is in contrast to our results, as we found that cotton is the source crop for A. lucorum mirid bugs at the Langfang station. This shows that the source-sink status of crops depends on the local environmental context (nature of crops present at a dispersal distance) and on the nature of pest species, with no general rules even for closely related organisms.

To evaluate the dispersal events between maize and cotton fields, we assumed that $A$. lucorum adults whose $\delta^{13} \mathrm{C}$ ratio corresponded to a $\mathrm{C}_{3}$ versus a $\mathrm{C}_{4}$ diet mostly fed on cotton versus maize at the juvenile stage. In our experiment, each year the three maize plots and the three cotton plots were randomly arranged in close proximity with no other plant around (weeds removed), hence we think that our assumption is relevant. In North-eastern China, maize and cotton are major crops, both economically and in terms of planted area, with 3-5 times larger areas planted with maize than with cotton (Fig. S3). Therefore, even though the very large areas planted with Bt cotton may cause major outbreaks of mirid bugs, the larger maize areas should help dampen those mirid outbreaks via their sink potential. In addition, maize and cotton fields are embedded in a mosaic of crops, including minor crops such as peanut and soybean, with maize often planted around cotton fields (Lu et al., 2010a, 2012a, 2012b). It makes sense to consider that the dispersal of A. lucorum adults may largely occur between maize and cotton fields, and the sink role of maize fields from source cotton fields is likely widespread at the landscape scale in North-eastern China (e.g. Anhui, Beijing, Hebei, Henan, Jiangsu, Tianjin and Shandong) where maize and cotton are largely embroiled in farmlands (Wu et al., 2004; Lu et al. 2012; Liu et al. 2016; MOA 2018; and see Fig. S3). This highlights the potential for maize to be used as a sink in this large cotton-growing region in China.

We measured A. lucorum population dynamics in maize and cotton fields that were similar to former studies (Lu et al., 2010a). Population densities peaked in August at roughly 50 individuals (adults plus juveniles) per 100 plant as in the treatments without insecticide in Lu et al. (2010a), except in 2013 when no large mirid oubtreak was measured (Fig. 4). Economically sustainable densities of mirid pests do not exceed ten individuals per 100 plants in cotton fields at the flowering stage, and insecticide spray would be used above this threshold to regulate mirid populations. We also confirmed that mirid bugs arrive in early July (or earlier) in cotton fields, but they were observed later in maize fields (late July to early August; Fig. S1; Lu et al., 2012b). At that time, maize is at the flowering / fruiting stage. The measure of life parameters of A. lucorum on different types of maize tissues (Fig. 5) showed that only grain and silk are valuable resources for the longevity of adults and the survival of juveniles, but only maize grain allows a high fecundity of A. lucorum. Therefore, maize is overall a poor host for A. lucorum and hence a good candidate for a sink strategy, in which the sink crop should attract dispersing individuals but cause a negative population growth rate (Holyoak, Leibold \& Holt, 2005). Since grain and silk maize resources are available late August only, this may explain why A. lucorum populations settle late in maize fields (as shown by the first day with juveniles observed in maize fields, Fig. S1).

Our high values of adults' longevity and fecundity on maize grain (Fig. 5) are comparable to those on cotton plants with flowers from Dong et al. (2013), while our low values on maize bract and tassel are comparable to those on cotton plants with no flowers from Dong et al. (2013). Although these unrelated studies cannot be easily compared due to their specific experimental contexts, this rough comparison hints that maize and cotton are comparable hosts. However, mirid outbreaks have been reported in cotton fields, but not in maize fields ( $\mathrm{Lu}$ et al. 2010). for both crops, the plant phenology is key to the establishment of mirid populations, and since cotton provides valuable resources for mirid bugs (flower buds and squares) earlier than maize, this may cause outbreaks in cotton fields only. 
We likely missed the arrival and population build-up of A. lucorum in cotton fields from spring hosts (Pan et al., 2014; 2015), due to a first sampling date in early July. However, we detected the first adults settling in, and we observed juveniles only later in maize fields. A possible reason causing a delay in population growth in maize is that juveniles cannot easily pierce bracts that protect maize grains, and thus have to use other plant resources, such as silk, bract or tassel, which develop later. The delayed establishment of $A$. lucorum populations in maize compared to cotton fields is consistent with a dispersal of adults from cotton to maize fields at the end of cotton flowering season.

The measure of stable carbon isotope ratios limits our understanding of the diet and dispersal of mirid bugs, which are highly polyphagous and opportunistic predators (Pan et al., 2019; Lu et al., Submitted). This is because $\mathrm{C}_{3}$ plants do not significantly differ in their $\delta^{13} \mathrm{C}$ signature once incorporated in mirids' diet, as shown in Fig. 1. This is why our interpretation that most A. lucorum adults likely disperse from cotton to maize fields in Bt cotton agricultural landscapes can only be hypothesized in our approach. Other methods, such as genomic shotgunsequencing of mirid gut content (Paula et al., 2016; Unruh et al., 2016) could provide more precise insights on the diet of omnivorous mirids. However, such methods inform on short-term diet only (a couple of days prior to sampling). Conversely, we showed that the $\mathrm{C}_{3}$ versus $\mathrm{C}_{4}$ signature caused by an imposed diet in laboratory conditions remained for nine days after a shift between the two types of diet (Fig. 2). Although nine days is relatively short compared to the longevity of A. lucorum measured in laboratory conditions (Fig. 5), it is closer to average longevity in field conditions, which is usually much shorter than in the laboratory due to life hazards and scarcity or poor quality of food resource.

Another limitation of the stable carbon isotope analysis is that it does not allow a direct measure of dispersal distance, which is yet a key element to implement efficient pest management strategies. For instance, Carrière et al. (2006) measured the spatial extent of the source and sink effects of different crops in Arizona cotton landscapes using global positioning system and geographic information system technologies, and were able to provide quantitative advises on crop spatial arrangement at a landscape scale, to improve the management of $L$. hesperus mirid pest populations. Other more direct methodologies, such as capture-markrecapture or immuno-marking (Lefebvre et al., 2017) could be used in combination with stable isotope analysis to measure arthropod pest dispersal capacities in specific agricultural landscapes.

Our finding that maize is a potential sink for mirid bugs from cotton plants provides new opportunities for the management of this pest species in cotton plants. While yield loss caused by mirid bugs in cotton plants are important even at low mirid densities, mirid bugs are not considered pests in maize, with no or little yield loss. This makes it even more interesting to enhance the sink potential of maize in pest management strategies targeting mirid outbreaks. If the current landscape practice consisting of planting maize around cotton fields is more systematically used, sink maize fields may help dampen mirid outbreaks by catching excess mirid adults from cotton fields and avoiding their dispersal in the neighbouring environment, since they seem to not disperse from maize fields. Containing mirid bugs in maize, from which they do not move and in which they do not optimally develop before the fruiting period, represents an immediate reduced pest pressure in the local environment. This landscape management would be especially useful to avoid dispersal of mirid bugs between cotton fields; they would instead be trapped in maize fields. Using the potential of maize as a sink crop for mirid pests from cotton fields should be tested at larger, landscape scales. It would be especially important to better characterize the dispersal of adult mirid bugs, including dispersal distance and direction of dispersal events, along the flowering season of cotton crop in different landscapes varying field size and the disposition and nature of alternative crops in Bt-cotton agricultural landscapes.

\section{Acknowledgments}

This study was supported by the National Natural Science Foundation of China (31621064) to ZJ, YHL, LFY and KMW, by the H2020 project EUCLID (633999) to YHL and ND, and by a Fyssen Postdoctoral Fellowship to CCJ.

\section{References}

Aviron, S., Poggi, S., Varennes, Y.-D. \& Lefèvre, A., 2016. Local landscape heterogeneity affects crop colonization by natural enemies of pests in protected horticultural cropping systems. Agric Ecosyst Environ 227, 1-10.

Baker, G. \& Tann, C., 2013. Mating of Helicoverpa armigera (Lepidoptera: Noctuidae) moths and their host plant origins as larvae within Australian cotton farming systems. Bull Entomol Res 103, 171-181.

Carrière, Y., Ellsworth, P.C., Dutilleul, P., Ellers-Kirk, C., Barkley, V. \& Antilla, L., 2006. A GIS-based approach for areawide pest management: the scales of Lygus hesperus movements to cotton from alfalfa, weeds, and cotton. Entomol Exp Appl 118, 203-210.

Dias, P.C., 1996. Sources and sinks in population biology. Trends Ecol Evol 11, 326-330.

Dong, J.-W., Pan, H.-S., Lu, Y.-H. \& Yang, Y.-Z., 2013. Nymphal performance correlated with adult preference for flowering host plants in a polyphagous mirid bug, Apolygus lucorum (Heteroptera: Miridae). Arthropod-Plant Interactions 7, 83-91.

Gould, F., Blair, N., Reid, M., Rennie, T.L., Lopez, J. \& Micinski, S., 2002. Bacillus thuringiensis-toxin resistance management: Stable isotope assessment of alternate host use by Helicoverpa zea. Proc Natl Acad Sci 99, 16581-16586.

Hanski, I., 1999. Metapopulation Ecology. Oxford University Press, Oxford, U.K.

Head, G., Jackson, R.E., Adamczyk, J., Bradley, J.R., Van Duyn, J., Gore, J., Hardee, D.D., Leonard, B.R., 
Luttrell, R., Ruberson, J., Mullins, J.W., Orth, R.G., Sivasupramaniam, S. \& Voth, R., 2010. Spatial and temporal variability in host use by Helicoverpa zea as measured by analyses of stable carbon isotope ratios and gossypol residues. J Appl Ecol 47, 583-592.

Holt, R.D, 1985. Population dynamics in two-patch environments : Some anomalous consequences of an optimal habitat distribution. Theor Popul Biol 28, 181-208.

Holoyak, M., Leibold, M.A. \& Holt R.D., 2005. Metacommunities : spatial dynamics ane ecological communities. The University of Chicago Press, Chicago, U.S.A.

Inclán, D.J., Cerretti, P. \& Marini, L., 2015. Landscape composition affects parasitoid spillover. Agric Ecosyst Environ 208, 48-54.

di Lascio, A., Madeira, F., Costantini, M.L., Rossi, L. \& Pons, X., 2016. Movement of three aphidophagous ladybird species between alfalfa and maize revealed by carbon and nitrogen stable isotope analysis. BioControl 61, 35-46.

Lefebvre, M., Papaïx, J., Mollot, G., Deschodt, P., Lavigne, C., Ricard, J.-M., Mandrin, J.-F. \& Franck, P., 2017. Bayesian inferences of arthropod movements between hedgerows and orchards. Basic Appl Ecol In press.

Li, G., Feng, H., McNeil, J.N., Liu, B., Chen, P. \& Qiu, F., 2011. Impacts of transgenic Bt cotton on a nontarget pest, Apolygus lucorum (Meyer-Dür) (Hemiptera: Miridae), in northern China. Crop Prot 30, 1573-1578.

Li, W., Wyckhuys, K.A.G. \& Wu, K., 2016. Does feeding behavior of a zoophytophagous mirid differ between host plant and insect prey items?. Arthropod-Plant Inte 10, 79-86.

Li, Y., Li, Z., Yang, Y., Yang, Q., Liu, X. \& Zhang, Q., 2015. Impact of food diversity on biological parameters of Apolygus lucorum (Hemiptera: Heteroptera: Miridae). Florida Entomolt 98, 11881192.

Liu, B., Yang, L., Yang, F., Wang, Q., Yang, Y.Z., Lu, Y.H., \& Gardiner, M.M., 2016. Landscape diversity enhances parasitism of cotton bollworm (Helicoverpa armigera) eggs by Trichogramma chilonis in cotton. Biol Control 93, 15-23.

Liu, Y., Duan, M. \& Yu, Z., 2013. Agricultural landscapes and biodiversity in China. Agric Ecosyst Environ 166, 46-54.

Lu, Y.-H., Li, W.-J., Jaworski, C.C., Wang, L.-L., Jiang, Y.-Y., Yang, F., Li, J.-H., Bao, W.-F., Wu, K.-M. \& Desneux, N., Submitted. Mirid bug outbreaks promote arthropod pest suppression in Bt cotton agro-ecosystems.

Lu, Y., Wu, K., Jiang, Y., Guo, Y. \& Desneux, N., 2012a. Widespread adoption of Bt cotton and insecticide decrease promotes biocontrol services. Nature 487, 362-365.

Lu, Y., Jiao, Z. \& Wu, K., 2012b. Early season host plants of Apolygus lucorum (Heteroptera: Miridae) in northern China. J Econ Entomol 105, 1603-1611.
Lu, Y. \& Wu, K., 2011. Mirid bugs in China: pest status and management strategies. Outlooks Pest Manag 22, 248-252.

Lu, Y., Wu, K., Jiang, Y., Xia, B., Li, P., Feng, H., Wyckhuys, K.A.G. \& Guo, Y., 2010a. Mirid bug outbreaks in multiple crops correlated with widescale adoption of Bt cotton in China. Science 328, 1151-1154.

Lu, Y., Wu, K., Wyckhuys, K.A. \& Guo, Y., 2010 b. Overwintering hosts of Apolygus lucorum (Hemiptera: Miridae) in northern China. Crop Prot 29, 1026-1033.

Lu, Y., Wu, K., Wyckhuys, K. \& Guo, Y., 2009. Potential of mungbean, Vigna radiatus as a trap crop for managing Apolygus lucorum (Hemiptera: Miridae) on Bt cotton. Crop Prot 28, 77-81.

Lu, Y.H. \& Wu, K.M., 2008. Biology and control of cotton mirids. Golden Shield Press, China.

Luo, S., Li, H., Lu, Y., Zhang, F., Haye, T., Kuhlmann, U. \& Wu, K., 2014. Functional response and mutual interference of Peristenus spretus (Hymenoptera: Braconidae), a parasitoid of Apolygus lucorum (Heteroptera: Miridae). Biocontrol Sci Tech 24, 247-256.

Meisner, M.H., Zaviezo, T. \& Rosenheim, J.A., 2016. Landscape crop composition effects on cotton yield, Lygus hesperus densities, and pesticide use. Pest Manag Sci 73, 232-239.

MOA 2018. Ministry of Agricultural and Rural Affairs of the People's Republic of China. http://zzys.agri.gov.cn/nongqingxm.aspx

Pan, H.S., Tena, A., Xiu, C.L., Liu, B., Lu, Y.H. \& Desneux, N., 2019. Floral-feeding increases diet breadth in a polyphagous mirid. J Pest Sci, Accepted.

Pan, H., Liu, B., Lu, Y. \& Wyckhuys, K.A.G., 2015. Seasonal alterations in host range and fidelity in the polyphagous mirid bug, Apolygus lucorum (Heteroptera: Miridae). PLoS ONE 10, 1-17.

Pan, H.S., Liu, B., Lu, Y.H. \& Desneux, N., 2014. Identification of the key weather factors affecting overwintering success of Apolygus lucorum eggs on withered plants. PLoS ONE. 9:e94190.

Pan, H., Lu, Y., Wyckhuys, K.A.G. \& Wu, K.M., 2013. Preference of a polyphagous mirid bug, Apolygus lucorum (Meyer-Dür) for flowering host plants. PLoS ONE 8, 1-16.

Paula, D.P., Linard, B., Crampton-Platt, A., Srivathsan, A., Timmermans, M.J.T.N., Sujii, E.R., Pires, C.S.S., Souza, L.M., Andow, D.A. \& Vogler, A.P., 2016. Uncovering trophic interactions in arthropod predators through DNA shotgun-sequencing of gut contents. PLoS ONE 11, 1-14.

Prasifka, J. \& Heinz, K., 2004. The use of C3 and C4 plants to study natural enemy movement and ecology, and its application to pest management. Int J Pest Manag 50, 177-181.

R Core Team (2015) R: A Language and Environment for Statistical Computing.

Raymond, L., Ortiz-Martínez, S.A. \& Lavandero, B., 2015. Temporal variability of aphid biological control in contrasting landscape contexts. Biol Control 90, 148-156. 
Schneider, G., Krauss, J., Riedinger, V., Holzschuh, A. \& Steffan-Dewenter, I., 2015. Biological pest control and yields depend on spatial and temporal crop cover dynamics. J Appl Ecol 52, 1283-1292.

Song, G.-J., Feng, H.-Q., Li, G.-P., Zhang, L.-X., Qiu, F. \& Li, H.-P., 2012a. Autumn migration of Apolygus lucorum in Henan Province revealed by the Rb marking technique. Chinese J Appl Entomol 49, 626-630.

Song, G.-J., Feng, H.-Q., Li, G.-P., Zhang, L.-X., Qiu, F. \& Li, H.-P., 2012b. Using the Rb marking technique to track the spring migration of Apolygus lucorum and Adelphocoris suturalis in Henan. Chinese J Appl Entomol 49, 620-625.

Tong, Y.-j., Wu, K.-m. \& Gao, X.-w., 2009. Predation of Misumenopos [Misumenops] tricuspidatus on mirids, Apolygus lucorum and Adelphocoris lineolatus. Chinese J Biol Control 25, 97-101.

Tscharntke, T., Tylianakis, J.M., Rand, T.A., Didham, R.K., Fahrig, L., Batáry, P., Bengtsson, J., Clough, Y., Crist, T.O., Dormann, C.F., Ewers, R.M., Fründ, J., Holt, R.D., Holzschuh, A., Klein, A.M., Kleijn, D., Kremen, C., Landis, D.A., Laurance, W., Lindenmayer, D., Scherber, C., Sodhi, N., Steffan-Dewenter, I., Thies, C., van der Putten, W.H. \& Westphal, C., 2012. Landscape moderation of biodiversity patterns and processes - eight hypotheses. Biol Rev 87, 661-685.

Tscharntke, T., Bommarco, R., Clough, Y., Crist, T.O., Kleijn, D., Rand, T.A., Tylianakis, J.M., van Nouhuys, S. \& Vidal, S., 2007. Conservation biological control and enemy diversity on a landscape scale. Biol Control 43, 294-309.

Unruh, T.R., Miliczky, E.R., Horton, D.R., ThomsenArcher, K., Rehfield-Ray, L. \& Jones, V.P., 2016. Gut content analysis of arthropod predators of codling moth in Washington apple orchards. Biol Control 102, 85-92.

Vasseur, C., Joannon, A., Aviron, S., Burel, F., Meynard, J.-M. \& Baudry, J., 2013. The cropping systems mosaic: How does the hidden heterogeneity of agricultural landscapes drive arthropod populations?. Agric Ecosyst Environ 166, 3-14.

Venugopal, P.D., Dively, G.P. \& Lamp, W.O., 2015. Spatiotemporal dynamics of the invasive Halyomorpha halys (Hemiptera: Pentatomidae) in and between adjacent corn and soybean fields. J Econ Entomol 108, 2231-2241.

Veres, A., Petit, S., Conord, C. \& Lavigne, C., 2013. Does landscape composition affect pest abundance and their control by natural enemies? A review. Agric Ecosyst Environ 166, 110-117.

Vialatte, A., Simon, J.-C., Dedryver, C.-A., Fabre, F. \& Plantegenest, M., 2006. Tracing individual movements of aphids reveals preferential routes of population transfers In agroecosystems. Ecol Appl 16, 839-844.

Wu, K., Feng, H., \& Guo, Y., 2004. Evaluation of maize as a refuge for management of resistance to $\mathrm{Bt}$ cotton by Helicoverpa armigera (Hubner) in the Yellow River cotton-farming region of China. Crop Protect 23, 523-530.

Zeilinger, A.R., Olson, D.M. \& Andow, D.A., 2016. Competitive release and outbreaks of non-target pests associated with transgenic Bt cotton. Ecol Appl 26, 1047-1054.

Zhang, P., Zhao, Y., Zhang, X., Song, Y., Zhang, Z. \& Liu, F., 2015. Field resistance monitoring of Apolygus lucorum (Hemiptera: Miridae) in Shandong, China to seven commonly used insecticides. Crop Prot 76, 127-133.

Zhou, Y.-L., Zhu, X.-Q., Gu, S.-H., huan Cui, H., Guo, Y.Y., Zhou, J.-J. \& Zhang, Y.-J., 2014. Silencing in Apolygus lucorum of the olfactory coreceptor Orco gene by RNA interference induces EAG response declining to two putative semiochemicals. J Insect Physiol 60, 31-39. 


\section{Supplementary Material}

Table S1. Tukey mean difference (first row) and $P$-values (second row) on $\delta^{13} \mathrm{C}$ values of A. lucorum adults reared on different plant species during the juvenile stage. Numbers in parenthesis are the number of replicates for each plant species.

\begin{tabular}{|c|c|c|c|c|c|c|c|c|c|}
\hline & $\begin{array}{l}\text { Maize } \\
(26)\end{array}$ & $\begin{array}{l}\text { Cotton } \\
\text { (5) }\end{array}$ & $\begin{array}{c}\text { Garden } \\
\text { balsam } \\
(5) \\
\end{array}$ & $\begin{array}{c}\text { Japanese } \\
\text { hop herb } \\
(5)\end{array}$ & $\begin{array}{c}\text { Green bean } \\
\text { (3) }\end{array}$ & $\begin{array}{c}\text { Castor oil } \\
\text { plant } \\
(5)\end{array}$ & $\begin{array}{l}\text { Peanut } \\
\text { (4) }\end{array}$ & $\begin{array}{c}\text { Alfalfa } \\
\text { (4) }\end{array}$ & $\begin{array}{c}\text { Carrot } \\
\text { (3) }\end{array}$ \\
\hline$\overline{\text { Cotton }}$ & $\begin{array}{c}-10.13 \\
<<0.001 \\
* * *\end{array}$ & & & & & & & & \\
\hline $\begin{array}{l}\text { Garden } \\
\text { balsam }\end{array}$ & $\begin{array}{c}-11.24 \\
<<0.001 \\
* * *\end{array}$ & $\begin{array}{c}-1.11 \\
0.50\end{array}$ & & & & & & & \\
\hline $\begin{array}{l}\text { Japanese hop } \\
\text { herb }\end{array}$ & $\begin{array}{c}-12.04 \\
<<0.001 \\
* * *\end{array}$ & $\begin{array}{l}-1.91 \\
0.016 \\
*\end{array}$ & $\begin{array}{l}-0.80 \\
0.86\end{array}$ & & & & & & \\
\hline Green bean & $\begin{array}{c}-12.48 \\
<<0.001 \\
* * *\end{array}$ & $\begin{array}{c}-2.35 \\
0.0080 \\
* *\end{array}$ & $\begin{array}{l}-1.24 \\
0.55\end{array}$ & $\begin{array}{c}-0.43 \\
0.99\end{array}$ & & & & & \\
\hline $\begin{array}{l}\text { Castor oil } \\
\text { plant }\end{array}$ & $\begin{array}{c}-13.06 \\
<<0.001 \\
* * *\end{array}$ & $\begin{array}{c}-2.93 \\
<<0.001 \\
* * *\end{array}$ & $\begin{array}{c}-1.82 \\
0.026 \\
*\end{array}$ & $\begin{array}{l}-1.02 \\
0.62\end{array}$ & $\begin{array}{l}-0.58 \\
0.99\end{array}$ & & & & \\
\hline Peanut & $\begin{array}{c}-13.19 \\
<<0.001 \\
* * *\end{array}$ & $\begin{array}{c}-3.07 \\
<<0.001 \\
* * *\end{array}$ & $\begin{array}{c}-1.96 \\
0.023 \\
*\end{array}$ & $\begin{array}{l}-1.15 \\
0.53\end{array}$ & $\begin{array}{c}-0.72 \\
0.98\end{array}$ & $\begin{array}{c}-0.14 \\
0.99\end{array}$ & & & \\
\hline Alfalfa & $\begin{array}{c}-13.62 \\
<<0.001 \\
* * *\end{array}$ & $\begin{array}{c}-3.50 \\
<<0.001 \\
* * *\end{array}$ & $\begin{array}{c}-2.39 \\
0.0021 \\
* *\end{array}$ & $\begin{array}{l}-1.58 \\
0.13\end{array}$ & $\begin{array}{l}-1.15 \\
0.70\end{array}$ & $\begin{array}{l}-0.57 \\
0.99\end{array}$ & $\begin{array}{c}-0.43 \\
0.99\end{array}$ & & \\
\hline Carrot & $\begin{array}{c}-13.67 \\
<<0.001 \\
* * *\end{array}$ & $\begin{array}{c}-3.54 \\
<<0.001 \\
\quad * * *\end{array}$ & $\begin{array}{c}-2.43 \\
0.0052 \\
* *\end{array}$ & $\begin{array}{c}-1.62 \\
0.19\end{array}$ & $\begin{array}{c}-1.19 \\
0.74\end{array}$ & $\begin{array}{c}-0.61 \\
0.99\end{array}$ & $\begin{array}{c}-0.47 \\
0.99\end{array}$ & $\begin{array}{c}-0.043 \\
1.00\end{array}$ & \\
\hline $\begin{array}{l}\text { Sunflower } \\
\text { (5) }\end{array}$ & $\begin{array}{c}-15.43 \\
<<0.001 \\
\quad * * *\end{array}$ & $\begin{array}{c}-5.30 \\
<<0.001 \\
* * *\end{array}$ & $\begin{array}{c}-4.19 \\
<<0.001 \\
* * *\end{array}$ & $\begin{array}{c}-3.39 \\
<<0.001 \\
* * *\end{array}$ & $\begin{array}{c}-2.95 \\
<0.001 \\
* * *\end{array}$ & $\begin{array}{c}-2.37 \\
<0.001 \\
* * *\end{array}$ & $\begin{array}{c}-2.24 \\
0.0051 \\
* *\end{array}$ & $\begin{array}{c}-1.81 \\
0.049 \\
*\end{array}$ & $\begin{array}{c}-1.76 \\
0.11\end{array}$ \\
\hline
\end{tabular}

Table S2. Tukey mean difference (first row) and $P$-values (second row) on $\delta^{13} \mathrm{C}$ values of A. lucorum adults fed on a different diet between juvenile and adult stages.

\begin{tabular}{|c|c|c|c|}
\hline Days after shift & 0 days & 3 days & 6 days \\
\hline \multicolumn{4}{|l|}{ Maize to cotton } \\
\hline 3 days & $\begin{array}{l}0.48 \\
0.80\end{array}$ & & \\
\hline 6 days & $\begin{array}{c}-0.68 \\
0.19\end{array}$ & $\begin{array}{c}-1.16 \\
0.20\end{array}$ & \\
\hline 9 days & $\begin{array}{c}-0.65 \\
0.31 \\
\end{array}$ & $\begin{array}{c}-1.13 \\
0.25 \\
\end{array}$ & $\begin{array}{c}0.034 \\
0.99 \\
\end{array}$ \\
\hline \multicolumn{4}{|l|}{ Cotton to maize } \\
\hline 3 days & $\begin{array}{l}1.67 \\
0.20\end{array}$ & & \\
\hline 6 days & $\begin{array}{c}3.91 \\
<<0.001 * * *\end{array}$ & $\begin{array}{c}2.23 \\
0.0013 * *\end{array}$ & \\
\hline 9 days & $\begin{array}{c}5.65 \\
<<0.001 * * *\end{array}$ & $\begin{array}{c}3.98 \\
<<0.001 * * *\end{array}$ & $\begin{array}{c}1.74 \\
0.054\end{array}$ \\
\hline
\end{tabular}

'*': $P<0.5 ;$;***': $P<0.001$. 
pest in Chinese Bt-cotton agro-landscapes. Supplementary Material.

Table S3. Tukey mean differences (first row) and $P$-values (second row) of survival rate of A. lucorum juveniles raised on four different maize tissues. Numbers in parentheses are the number of replicates for each plant tissue.

\begin{tabular}{lccc}
\hline Maize tissue & silk (3) & tassel (4) & bract (3) \\
\hline grain (8) & 1.84 & 50.56 & 55.19 \\
& 0.99 & $<0.001 * * *$ & $<0.001^{* * *}$ \\
silk (3) & & 48.71 & 53.35 \\
& & $<0.001 * * *$ & $<0.001 * * *$ \\
tassel (4) & & & 4.63 \\
\end{tabular}

***': $P<0.001$.

Table S4. Tukey mean differences (first row) and P-values (second row) of development duration of A. lucorum juveniles raised on four different maize tissues. Numbers in parentheses are the number of replicates for each maize tissue.

\begin{tabular}{lccc}
\hline Maize tissue & silk (68) & tassel (20) & bract (10) \\
\hline grain (42) & -1.07 & -1.39 & -5.49 \\
& $<0.001 * * *$ & $0.0019^{* *}$ & $<0.001^{* * *}$ \\
silk (68)) & & -0.32 & -4.42 \\
& & 0.81 & $<0.001 * * *$ \\
tassel (20) & & & -4.10 \\
\end{tabular}

‘**': $P<0.01$; $^{\text {'***': } P<0.001 .}$

Table S5. Tukey mean differences (first row) and $P$-values (second row) of longevity of A. lucorum adults raised on four different maize tissues. Numbers in parentheses are the number of replicates for each maize tissue.

\begin{tabular}{lccc}
\hline Maize tissue & silk (50) & tassel (40) & bract (40) \\
\hline grain (78) & 0.38 & 23.52 & 25.39 \\
& 0.99 & $<0.001 * * *$ & $<0.001 * * *$ \\
silk (50) & & 23.13 & 25.01 \\
& & $<0.001 * * *$ & $<0.001 * * *$ \\
tassel (40) & & & 1.88 \\
& & & 0.93 \\
\hline
\end{tabular}

'***': $P<0.001$.

Table S6. Tukey mean difference (first row) and $P$-values (second row) of fecundity for A. lucorum adults raised on four different maize tissues. Numbers in parentheses are the number of replicates for each maize tissue.

\begin{tabular}{lccc}
\hline Maize tissue & silk (25) & tassel (20) & bract (20) \\
\hline grain (40) & 82.37 & 95.53 & 100.23 \\
& $<0.001^{* * *}$ & $<0.001 * * *$ & $<0.001^{* * *}$ \\
silk (25) & & 13.16 & 17.86 \\
& & 0.87 & 0.73 \\
tassel (20) & & & 4.70 \\
\end{tabular}

'***': $P<0.001$. 


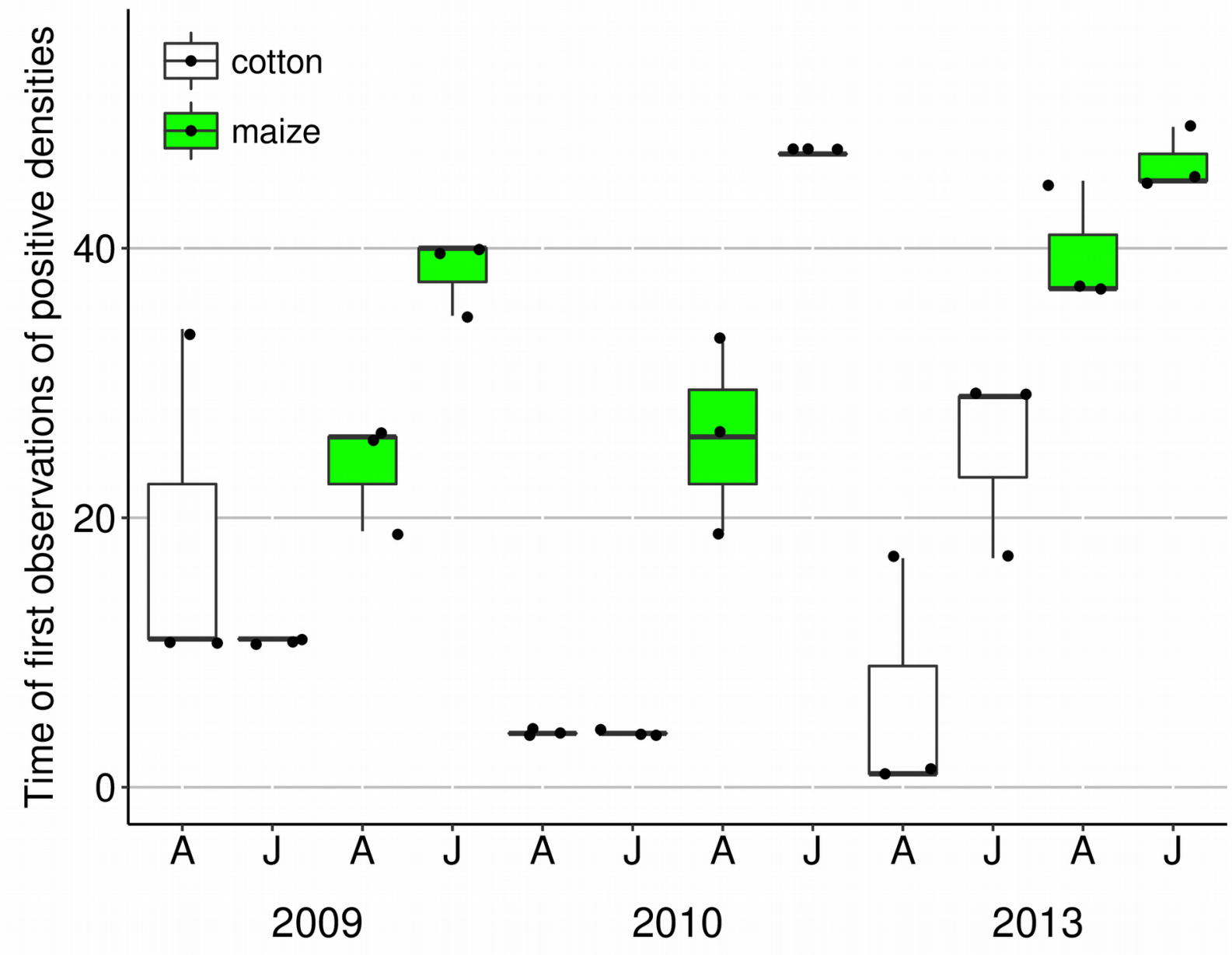

Figure S1. First day with observed positive densities of $A$. lucorum adults and juveniles in cotton (white bars) and maize fields (green bars) in summers 2009, 2010 and 2013, at the Langfang station.

Adults' and juveniles' dates are indicated by A and J below boxplots, respectively, with black dots representing the data points $(\mathrm{N}=3)$. Days are counted since July $1^{\text {st }}$ of each year.

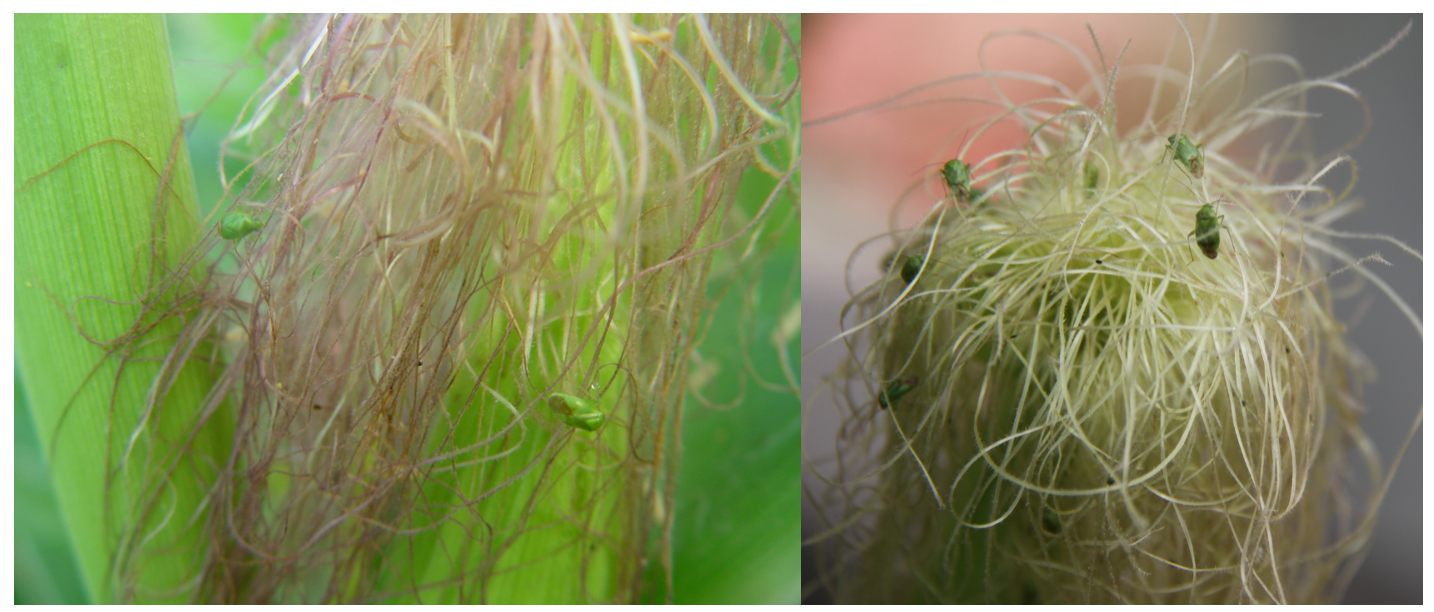

Figure S2. Mirid bugs feeding on silks of ripening corn fruits. 


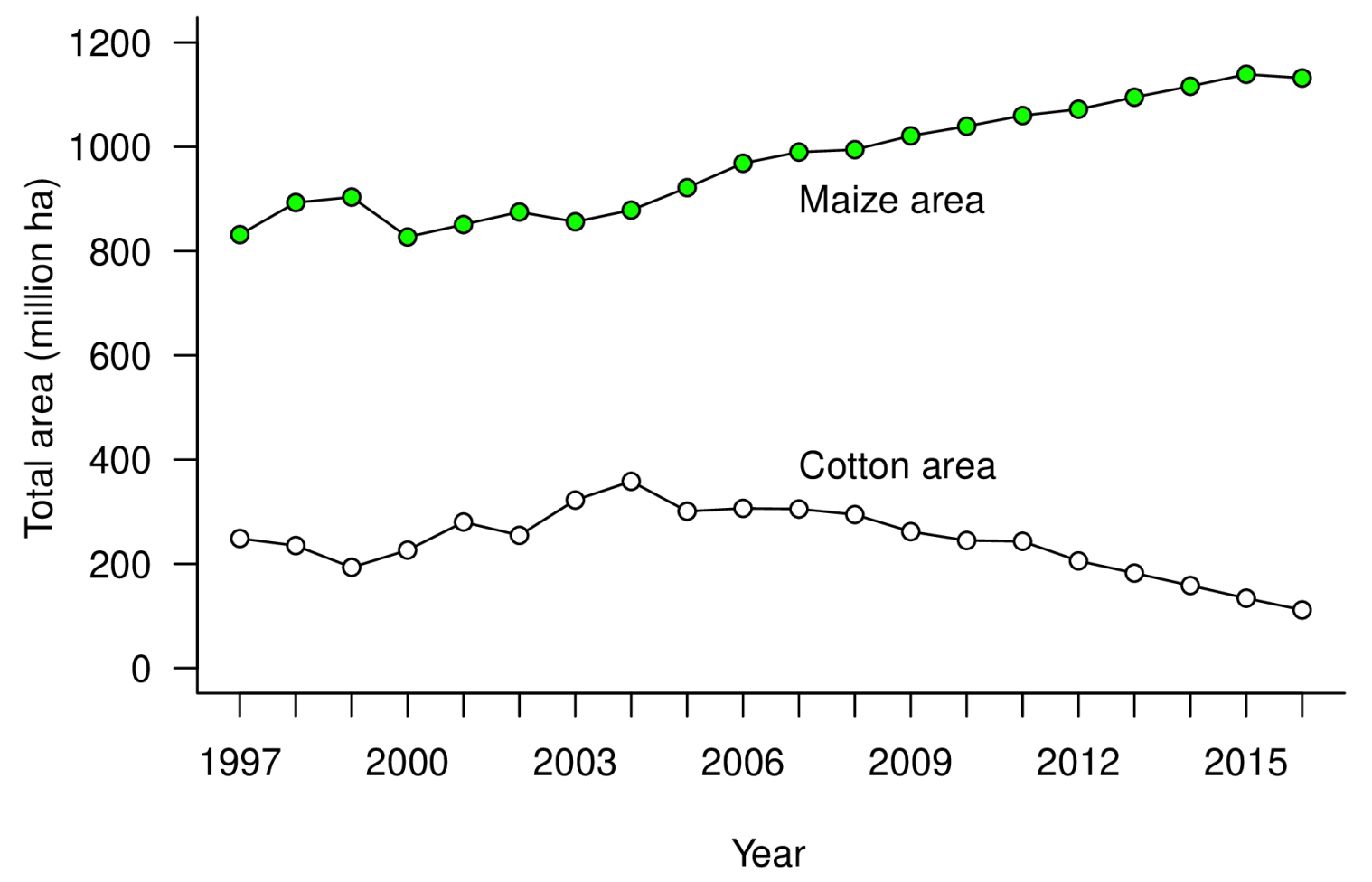

Figure S3. Evolution of maize- and cotton-planted areas in North China from 1997 to 2016, including the provinces of Beijing, Tianjin, Shandong, Hebei, Jiangsu, Henan and Anhui. Data provided by the Ministry of Agriculture and Rural Affairs of the People's Republic of China (MOA 2018; http://zzys.agri.gov.cn/nongqingxm.aspx). 